\title{
Differential effects of IGF-binding proteins, IGFBP-3 and IGFBP-5, on IGF-I action and binding to cell membranes of immortalized human chondrocytes
}

\author{
T Matsumoto, T Tsurumoto, M B Goldring ${ }^{1}$ and H Shindo \\ Department of Orthopedic Surgery, School of Medicine, Nagasaki University, Nagasaki 852-8501, Japan \\ ${ }^{1}$ New England Baptist Bone and Joint Institute and Rheumatology Division, Beth Israel Deaconess Medical Center, Harvard Institutes of Medicine, Boston, \\ Massachusetts 02115, USA \\ (Requests for offprints should be addressed to T Matsumoto, Department of Orthopedic Surgery, School of Medicine, Nagasaki University, Nagasaki, \\ Sakamoto 1-7-1, 852-8501, Japan)
}

\begin{abstract}
Insulin-like growth factor-I (IGF-I) is an important anabolic factor for cartilage tissue and its action is, in part, regulated by IGF-binding proteins (IGFBPs). The object of this study was to investigate the effects of IGFBPs on IGF-I action and on binding of IGF-I to cells using a reproducible immortalized human chondrocyte culture model. Treatment of the C-28/I2 cells with IGF-I or des(1-3)IGF-I in serum-free medium stimulated cell proliferation in a dose-dependent manner. However, the effect of des(1-3)IGF-I was more potent, thereby suggesting that endogenously produced IGFBPs inhibited IGF action. The stimulatory effect of IGF-I was inhibited significantly by addition of IGFBP-3 but enhanced slightly by IGFBP-5. However, neither IGFBP-3 nor IGFBP-
\end{abstract}

5 had an effect on basal cell growth. Binding of ${ }^{125} \mathrm{I}-$ labeled IGF-I to the cells was displaced by both IGFBP-3 and IGFBP-5, although higher concentrations of unlabeled IGFBP-5 were required to displace IGF-I to the same extent as IGFBP-3. Treatment of the cells with IGF-I increased the levels of IGFBP-5 protein measured by Western ligand blotting, and stimulated a corresponding increase in IGFBP-5 mRNA while increasing type II collagen mRNA. Our findings indicate that the balance between IGFBP-3 and IGFBP-5 influences IGF receptor binding and its action on chondrocyte proliferation, and may thereby modulate cartilage metabolism.

Journal of Endocrinology (2000) 166, 29-37

\section{Introduction}

The insulin-like growth factor (IGF)-I is a major growth and differentiation factor for cartilage tissue (McQuillan et al. 1986, Ohlsson et al. 1992, Seong et al. 1994) and its influence on chondrocyte functions is regulated, in part, by IGF-binding proteins (IGFBPs) (Lamson et al. 1991, Jones \& Clemmons 1995). At present, six IGFBPs (IGFBPs-1 to -6) have been isolated and their cDNAs have been cloned (Shimasaki \& Ling 1991). IGFBPs have been detected in culture media of cultured chondrocytes from various species (Froger-Gaillard et al. 1989, Olney et al. 1993, Sunic et al. 1995) and in intact bovine cartilage (Morales 1997).

We reported previously that the predominant IGFBPs produced by rat articular chondrocytes were IGFBPs-2, $-3,-4$ and -5 , and that the concentration of IGFBP-5 in conditioned medium was increased by IGF-I in a dosedependent manner by a transcriptional mechanism via the type 1 IGF receptor (Matsumoto et al. 1996a). We also detected the presence of an IGFBP-5 protease (Matsumoto et al. 1996b), suggesting post-translational modification as an additional mechanism of IGFBP regulation. Although the physiological roles of these IGFBPs in cartilage metabolism remain to be clarified, various studies have begun to address how IGFBPs may exert differential effects on the systemic and local activities of IGF-I. In osteoarthritic cartilage, the normal anabolic function of IGF-I may be disrupted. Chondrocytes from animals with experimental arthritis and from patients with osteoarthritis are nonresponsive to IGF-I, although they express increased levels of IGF-I, IGF-I receptor, and IGFBPs-2, -3 and -5 (Middleton \& Tyler 1992, Dore et al. 1994, Olney et al. 1996). Since IGFBP-3 and IGFBP-5 have been shown to have both similar and opposing effects in different experimental models, we investigated the interaction between IGF-I and these IGFBPs in human chondrocytes. 


\section{Materials and Methods}

\section{Materials}

Recombinant human (rh) IGF-I and des(1-3)IGF-I were obtained from Gropep (Adelaide, Australia). Recombinant human IGFBP-3 and polyclonal antibody to IGFBP-2 and IGFBP-3 were generous gifts from Dr Y Oh (Oregon Health Sciences University, Portland, OR, USA). IGFBP-5 was purchased from Austral Biologicals (San Ramon, CA, USA). A polyclonal antibody to IGFBP-5 was obtained from Upstate Biotechnology (Lake Placid, NY, USA). Dulbecco's modified Eagle's medium (DMEM) and heat-inactivated fetal calf serum (FCS) were purchased from Gibco BRL (Grand Island, NY, USA).

\section{Cell cultures}

The immortalized human chondrocytes used in this study, the C-28/I2 cell line, were established using a retrovirus expressing simian virus 40 large tumor antigen (SV40$\mathrm{TAg}$ ) and the neomycin-resistance selection marker (neoR), as described by Goldring et al. (1994). These cells, which were derived from juvenile costal cartilage, express the differentiated chondrocyte phenotypic markers of type II collagen and aggrecan, but not the hypertropic chondrocyte marker, type $\mathrm{X}$ collagen. Cultures were maintained in a $5 \% \mathrm{CO}_{2}$ incubator at $37{ }^{\circ} \mathrm{C}$ in DMEM supplemented with 10\% FCS and were continuously passaged at subconfluency. Prior to experimental incubations, the chondrocytes were resuspended in DMEM supplemented with 10\% FCS and seeded at a density of $200000 \mathrm{cells} / \mathrm{cm}^{2}$ in $96-\mathrm{well}$ plates for cell proliferation studies, in 24-well plates for receptor binding studies, in 12 -well plates for affinity cross-linking studies, or in $10-\mathrm{cm}$ plates for total RNA extraction. The medium was then changed to serum-free medium containing $0 \cdot 3 \%$ bovine serum albumin.

\section{Cell proliferation}

In order to determine the effects of IGF-I and IGFBPs on cell proliferation, the C-28/I2 cells were plated in 96-well plates. The cells were grown to subconfluence for 3 days, following which the cultures were changed to serum-free DMEM and incubated for $24 \mathrm{~h}$. The medium was then replaced with DMEM containing various concentrations of IGF-I or IGFBPs, and incubations were continued for a further $48 \mathrm{~h}$. Cell proliferation was then determined by a nonisotopic method based on measurement of acid phosphatase levels using a cell counting kit (Abacus Cell Proliferation Kit, Clontech, Palo Alto, CA, USA). Six replicates were used for each treatment.

\section{Effect of IGFBPs on IGF-I binding to cells}

In order to determine the effects of IGFBPs on IGF-I binding to chondrocytes, cells were plated in 24-well plates. After $24 \mathrm{~h}$ incubation without serum, various concentrations of IGFBPs were added and then cells were incubated with ${ }^{125}$ I-labeled IGF-I (40 000 c.p.m.) for $3 \mathrm{~h}$ at room temperature. ${ }^{125}$ I-labeled IGF-I bound to cells was extracted with $0.5 \mathrm{M} \mathrm{NaOH}$ and counted using a $\gamma$-counter.

\section{Affinity cross-linking}

Confluent chondrocytes in 12-well plates were washed with PBS and incubated with ${ }^{125}$ I-labeled IGF-I or ${ }^{125}$ I-labeled IGF-II $\left(4 \times 10^{5}\right.$ c.p.m./well $)$ with or without unlabeled IGFs in $50 \mathrm{mM}$ HEPES binding buffer containing $1 \% \mathrm{BSA}$, overnight at $4{ }^{\circ} \mathrm{C}$. The buffer was aspirated, and cross-linking was performed with disuccinimidyl substrate for $15 \mathrm{~min}$ at $4{ }^{\circ} \mathrm{C}$. The reaction was quenched with $0.1 \mathrm{M}$ Tris-10 mM EDTA. Cells were solubilized and the lysates were separated by $10 \%$ SDSpolyacrylamide gel electrophoresis. Gels were dried and exposed to X-ray film for 3 days.

\section{Western ligand blotting and immunoblotting}

Western ligand blots (WLB) were carried out according to the method of Hossenlopp et al. (1986). Briefly, conditioned medium samples $(100 \mu \mathrm{l})$ from chondrocytes treated with or without IGF-I for $48 \mathrm{~h}$ were separated by $12.5 \%$ SDS-polyacrylamide gel electrophoresis. Proteins were then electrotransferred onto nitrocellulose filters. The filters were washed in 3\% NP40 in Tris-buffered saline (TBS) for $30 \mathrm{~min}$, and then incubated with 1\% BSA in TBS for $2 \mathrm{~h}$. The treated nitrocellulose filters were probed with $1 \times 10^{6}$ c.p.m. radiolabeled IGF-I and IGF-II overnight. The filters were visualized by autoradiography.

For immunoblotting, filters were blocked with 5\% BSA overnight at $4{ }^{\circ} \mathrm{C}$, incubated for $2 \mathrm{~h}$ with antiserum $(1: 500$ dilution), and then incubated for $2 \mathrm{~h}$ with goat anti-rabbit immunoglobulin $\mathrm{G}(\mathrm{IgG})$-alkaline phosphatase conjugate. Antigen-antibody reactions were visualized using amplified alkaline phosphatase immunoblotting reagents following the manufacturer's instructions (Bio-Rad, Richmond, CA, USA).

\section{Extraction and analysis of $m R N A s$}

The cells were grown to subconfluence in $10-\mathrm{cm}$ dishes for 3 days, following which the medium was changed to serum-free medium containing $0 \cdot 3 \%$ bovine serum albumin and incubation continued for 16-24 h. IGF-I $(100 \mathrm{ng} / \mathrm{ml})$ was then added to test cultures without medium change and incubations continued for a further $48 \mathrm{~h}$. Total RNA was extracted from cell layers using guanidine thiocyanate with high volume $\mathrm{LiCl}$ precipitation, followed by phenol/chloroform/isoamyl alcohol extraction and EtOH precipitation as described (Cathala et al. 1983, Goldring 1996). Semi-quantitative reverse 


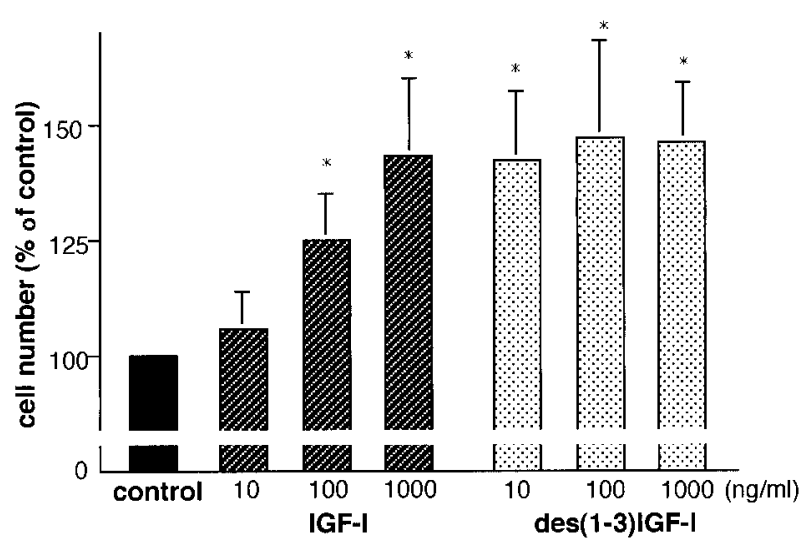

Figure 1 Effects of IGF-I and des(1-3)IGF-I on cell proliferation. Chondrocytes were incubated for $48 \mathrm{~h}$ with or without (control) IGF-I or the IGF analog, des(1-3)IGF-I. Cell numbers were examined as described in Materials and Methods. Values are expressed as a percentage of the untreated control. Error bars give the standard deviation. ${ }^{*} P<0 \cdot 001$ compared with control.

transcriptase-polymerase chain reaction (RT-PCR) for rapid screening of mRNAs was carried out using the GeneAmp Thermostable rTth RT-PCR Kit (Perkin Elmer, Foster City, CA, USA). Primers for glyceraldehyde3-phosphate dehydrogenase (GAPDH) and collagen II were as described by Lum et al. (1996), and for IGFBPs-2, $-3,-4$ and -5 were as described by Olney et al. (1995).

\section{Statistical analysis}

The results are presented as means \pm S.D. Statistical analysis was undertaken using one-way analysis of variance (ANOVA) with Scheffe's F test.

\section{Results}

Effects of IGF-I and des(1-3)IGF-I on cell proliferation

IGF-I at 10,100 and $1000 \mathrm{ng} / \mathrm{ml}$ stimulated proliferation of chondrocytes to $106 \pm 8,125 \pm 10$ and $143 \pm 17 \%$ of control respectively. However, des(1-3)IGF-I, which is an analog of IGF-I with $>100$-fold reduced affinity for IGFBPs but normal affinity for the type 1 IGF receptor, was more potent than native IGF-I in stimulating cell growth at $10 \mathrm{ng} / \mathrm{ml}(142 \pm 15 \%$ of control $)$ and $100 \mathrm{ng} / \mathrm{ml}$ (147 $\pm 21 \%$ of control) (Fig. 1). These findings suggest that interaction of native IGF-I with its receptor may be attenuated by bound IGFBP(s) which do not interfere with receptor binding of the analog.

\section{Inhibition of IGF-I-stimulated cell proliferation by IGFBP-3 but not by IGFBP-5}

Since IGFBP-3 and IGFBP-5 have been shown to have both stimulatory and inhibitory actions on IGF-I action and are expressed differentially in normal and arthritic chondrocytes, we examined the effect of IGFBP-3 or IGFBP-5 on IGF-I-stimulated cell proliferation when co-incubated with IGF-I. Neither IGFBP-3 nor IGFBP-5 $(100-1000 \mathrm{ng} / \mathrm{ml})$ had any significant effect on proliferation of chondrocytes in the absence of IGF-I (Fig. 2). At $100 \mathrm{ng} / \mathrm{ml}$, IGF-I stimulated cell proliferation to $139 \pm 7 \%$ of control, and this stimulatory effect of IGF-I was inhibited significantly to $123 \pm 7 \%$ and $111 \pm 3 \%$ in the presence of 500 and $1000 \mathrm{ng} / \mathrm{ml}$ IGFBP-3 respectively $(P<0.001$ versus IGF-I-treated without IGFBP). In contrast, IGFBP-5 did not show any inhibitory effect but rather a slightly stimulatory effect on the IGF-I-induced cell proliferation, to $152 \pm 5 \%$ at $500 \mathrm{ng} / \mathrm{ml}(P<0 \cdot 001$ versus IGF-I-treated without IGFBP).

\section{Displacement of binding of ${ }^{125}$ I-labeled IGF-I to C-28/I2 cells by IGFBP-3 and IGFBP-5}

We examined the effects of IGFBPs on binding of IGF-I to the cell membrane by incubating cells with ${ }^{125}$ I-labeled IGF-I with or without unlabeled IGFBP-3 or IGFBP-5 $(1-500 \mathrm{ng} / \mathrm{ml})$. The binding of ${ }^{125}$ I-labeled IGF-I to the cell membrane was displaced by either IGFBP-3 or IGFBP-5 in a dose-dependent manner. However, the reduction in the binding of IGF-I tracer produced by IGFBP-3 was more potent than that produced by IGFBP-5. At $250 \mathrm{ng} / \mathrm{ml}$ unlabeled IGFBP-3 or IGFBP-5, the binding of ${ }^{125}$ I-labeled IGF-I to chondrocytes $\left(\mathrm{B} / \mathrm{B}_{0}\right)$ was decreased to $18 \%$ or $77 \%$ respectively (Fig. 3).

Affinity cross-linking of ${ }^{125}$ I-labeled IGF-I and ${ }^{125}$ I-labeled IGF-II to chondrocytes

The affinity cross-linking of ${ }^{125}$ I-labeled IGF-I and ${ }^{125} \mathrm{I}-$ labeled IGF-II to the cell surface was then examined (Fig. 4). After separation of ${ }^{125}$ I-labeled IGF-I cross-linked proteins by SDS-polyacrylamide gel electrophoresis under reducing conditions, a band of 137 kilodaltons $(\mathrm{kDa})$, consistent with the size of the IGF-I receptor $\alpha$-subunit, was observed (Fig. 4, lanes 1 and 2). This band was attenuated in the presence of unlabeled $200 \mathrm{ng} / \mathrm{ml}$ IGF-I (lanes 3 and 4) and to a lesser extent by $200 \mathrm{ng} / \mathrm{ml} \mathrm{IGF-II}$ (lanes 5 and 6). Two bands of more than $200 \mathrm{kDa}$ may represent cross-linked $\alpha$-subunits of the IGF-I receptor.

After separation of ${ }^{125}$ I-labeled IGF-II cross-linked proteins by SDS-polyacrylamide gel electrophoresis, a band of more than $200 \mathrm{kDa}$, consistent with the IGF-II/ mannose 6-P receptor, was seen (Fig. 4, lanes 7 and 8). This band was not abolished by addition of $200 \mathrm{ng} / \mathrm{ml}$ IGF-I, but it was attenuated by $200 \mathrm{ng} / \mathrm{ml}$ IGF-II. ${ }^{125}$ I-labeled IGF-II also bound to a doublet protein at approximately $50 \mathrm{kDa}$, and the binding was decreased by unlabeled IGF-II (Fig. 4, lanes 7 and 8). After subtraction of the molecular weight of the ligand (IGF-II), these bands were found to correspond to a cell-associated IGFBP-3 
A

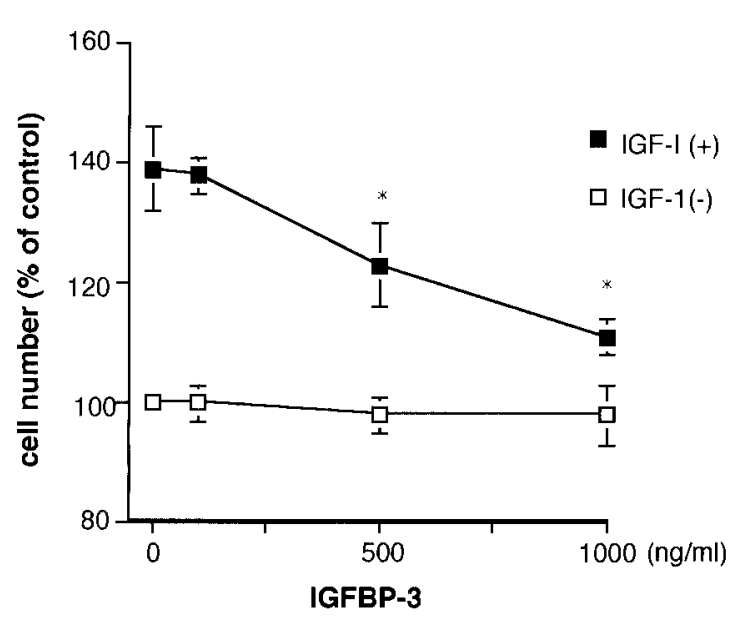

B

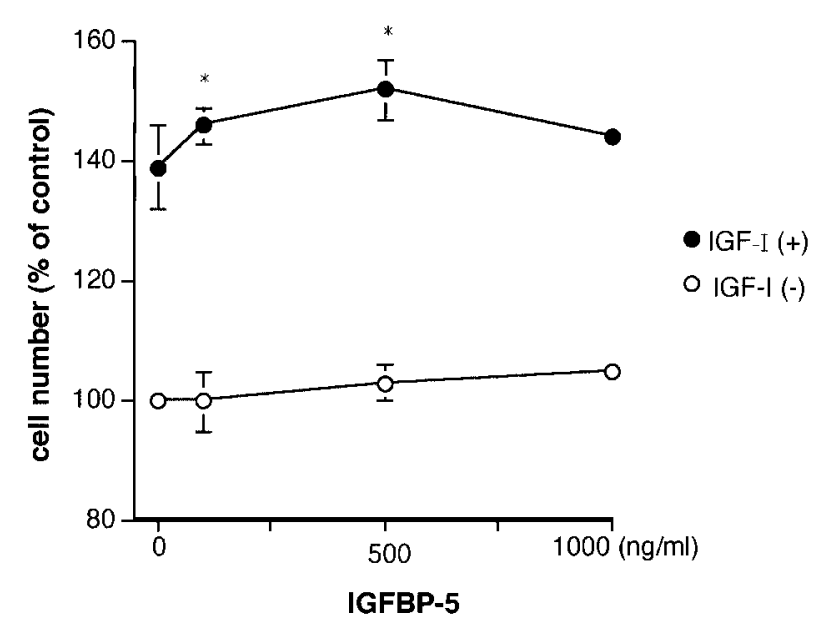

Figure 2 Effects of IGFBPs on basal and IGF-I-induced cell proliferation. Panel A shows the effects of increasing concentrations of IGFBP-3 on cell proliferation in the presence (solid squares) or absence (open squares) of $100 \mathrm{ng} / \mathrm{ml}$ IGF-I. Panel B shows the effects of increasing concentrations of IGFBP-5 on cell proliferation in the presence (solid circles) or absence (open circles) of $100 \mathrm{ng} / \mathrm{ml}$ IGF-I. Values are expressed as a percentage of the untreated control. Error bars give the standard deviation. ${ }^{*} P<0 \cdot 001$ compared with the IGF-I control (treated with $100 \mathrm{ng} / \mathrm{ml} \mathrm{IGF-I} \mathrm{without} \mathrm{IGFBP).}$

doublet of $40 \mathrm{kDa}$ and $38 \mathrm{kDa}$. In addition, a faint band at $37 \mathrm{kDa}$ was detected, which was diminished by $200 \mathrm{ng} /$ $\mathrm{ml}$ IGF-I and IGF-II, thus suggesting the presence of cell-associated IGFBP-5. However, in order to determine that the binding was to specific membrane-associated proteins, rather than to the proteins secreted during the incubation period, further studies using membrane preparations will be needed.

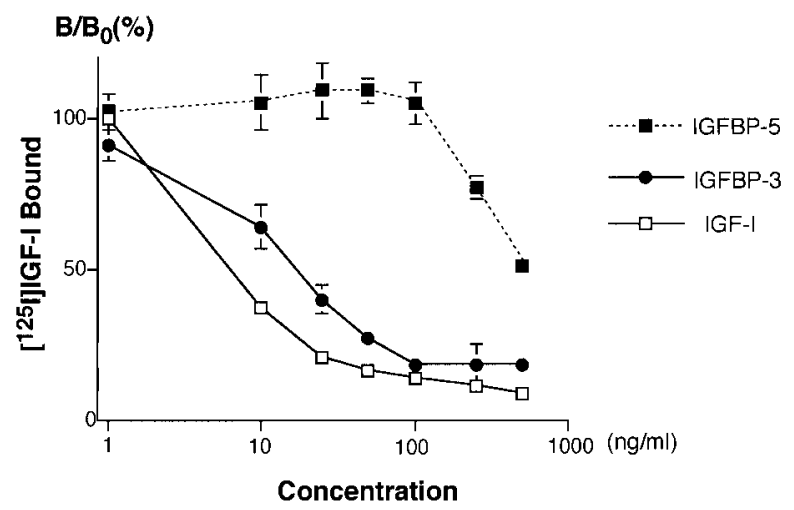

Figure 3 Effect of IGF-I and IGFBPs on the binding of ${ }^{125}$ I-labeled IGF-I to cells. Competition by IGF-I (open squares), IGFBP-3 (solid circles), and IGFBP-5 (solid squares) incubated simultaneously with labeled IGF-I. Results are expressed as a percentage of binding ${ }^{125}$ I-labeled IGF-I in the absence $\left(\mathrm{B}_{0}\right)$ and presence $(\mathrm{B})$ of cold ligand. Error bars give the standard deviation.
Stimulation of IGFBP-5 by IGF-I at the protein and $m R N A$ levels

To identify the IGFBPs produced by the C-28/I2 cells and to determine IGF-mediated changes, the cells were treated with IGF-I for $48 \mathrm{~h}$ and the serum-free conditioned medium was subjected to WLB analysis. In the absence of IGF-I, binding to radiolabeled IGF-I was detected as a $39 / 43 \mathrm{kDa}$ doublet band, a $33 \mathrm{kDa}$ band and a $24 \mathrm{kDa}$ band. IGF-I induced the appearance of a band at $29 \mathrm{kDa}$, with a maximal effect at $100 \mathrm{ng} / \mathrm{ml}$, but also slightly increased the other IGFBPs (Fig. 5). Immunoblotting with anti-IGFBPs-2, $-3,-4$, and -5 antibodies showed that the $33 \mathrm{kDa}$ band was IGFBP-2, the 39/ $43 \mathrm{kDa}$ doublet was IGFBP-3, the $24 \mathrm{kDa}$ band was IGFBP-4, and the $29 \mathrm{kDa}$ band was IGFBP-5 (Fig. 6). Treatment of the C-28/I2 cells with IGF-I at $100 \mathrm{ng} / \mathrm{ml}$ also stimulated a corresponding increase in IGFBP-5 and type II collagen mRNAs, but not IGFBPs-2, -3 , and -4 mRNAs (Fig. 7).

\section{Discussion}

In the present study, we found that IGFBP-3 and IGFBP-5 differentially modulated the action of IGF-I on cell proliferation in immortalized human chondrocytes. Although neither IGFBP affected cell proliferation in the absence of IGF-I, IGFBP-3 but not IGFBP-5 inhibited IGF-induced cell proliferation. A role for endogenous 


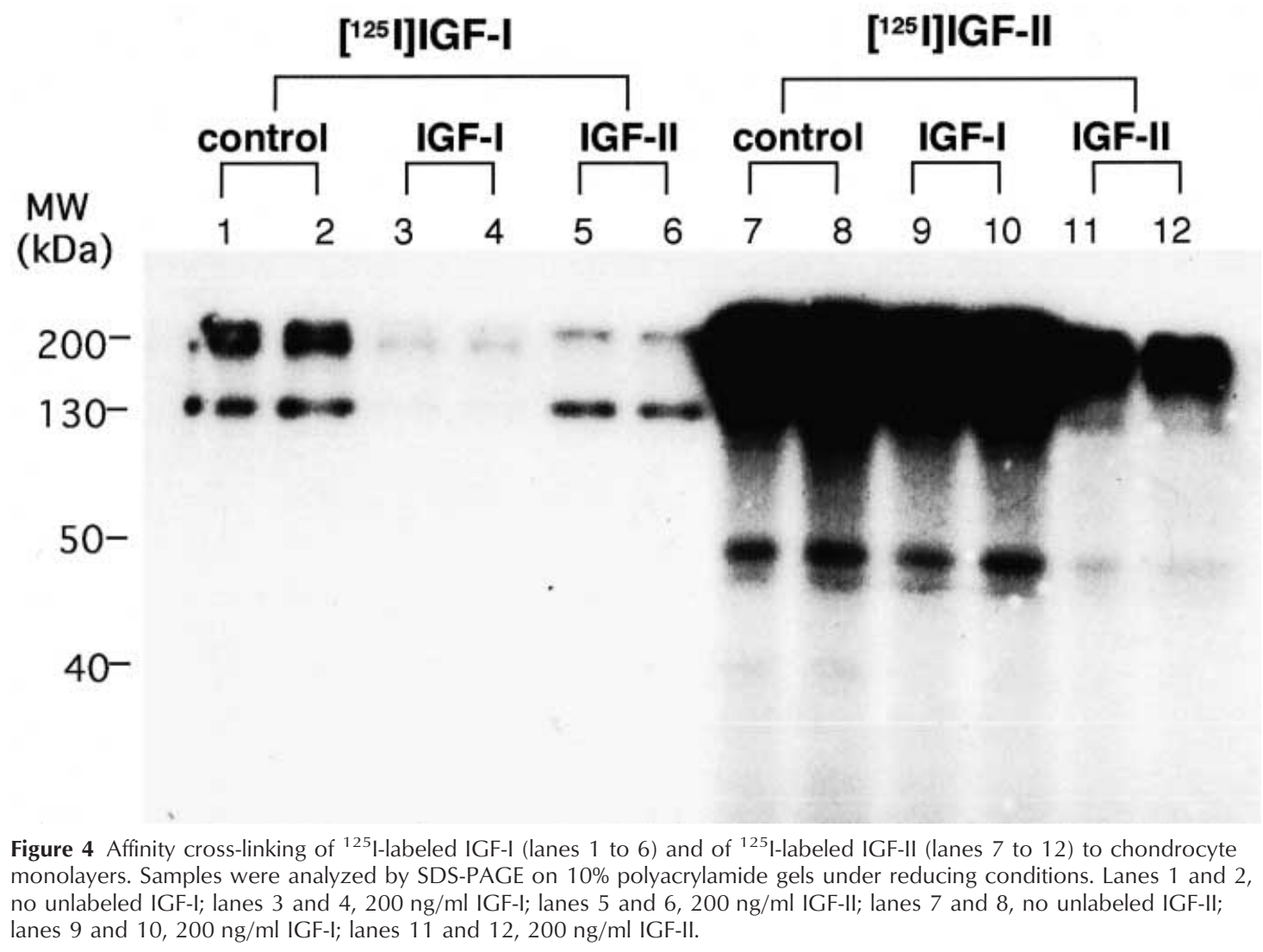

IGFBPs in regulating IGF-I action was also suggested by the fact that des(1-3)IGF-I, which exhibits unaltered affinity for the IGF-I receptor, but weak or almost no binding to IGFBPs, was more potent in increasing cell proliferation than native IGF-I. The mechanism of the inhibitory effect might be explained by the ability of soluble IGFBPs to prevent IGF-I from binding to the type 1 IGF receptor. As expected, IGFBP-3 clearly inhibited the binding of IGF-I to cell membranes in this study. The inhibitory effect of IGFBP-3 on IGF-induced cell proliferation has also been shown in fibroblasts (DeMellow \& Baxter 1988, Okajima et al. 1993) and osteoblasts (Schmid et al. 1991, Andress \& Birnbaum 1992); however, some conflicting observations were reported (Cornell et al. 1987, Conover et al. 1990). Different experimental conditions, such as preincubation rather than coincubation with the IGFBP, or alteration in the molar ratio of IGF to IGFBP, may affect these results. How changes in the endogenous levels of IGF-I and IGFBPs may influence the responses in these cells remains to be clarified.

On the other hand, IGFBP-5 did not inhibit, but rather slightly enhanced IGF-I-induced cell proliferation. Although the inhibitory effect of IGFBP-5 on IGF-I binding to cell membranes was much less than that of IGFBP-3, high concentrations of IGFBP-5 prevented
IGF-I binding to the cells in this study. These findings give no appropriate explanation for why IGFBP-5 did not inhibit IGF-I-induced cell proliferation. Although molar excess of IGFBP-5 was reported to inhibit IGF-I action in osteosarcoma cells (Kiefer et al. 1992), the usual observation is that IGFBP-5 enhances IGF-I activity on mitogenesis in osteoblasts or fibroblasts via binding to the extracellular matrix (Andress \& Birnbaum 1992, Jones et al. 1993). Whether a given IGFBP potentiates or inhibits IGF-I action appears to depend upon the relative levels of cell-associated and soluble extracellular IGFBP, as well as on the ratio of IGFBP to IGF-I (Jones \& Clemmons 1995, Kelley et al. 1996). Although it is more complicated to understand the potentiation mechanism of IGFBPs, it is assumed that cell- associated IGFBPs, having a lower affinity for IGFs than soluble IGFBPs (McCusker et al. 1990, McCusker \& Clemmons 1997) may play some part in enhancing IGF activity. Furthermore, there is the other possibility that IGFBP-5 proteolysis has effects on IGF action; however, we have not yet examined the IGFBP-5 protease in this model.

The immortalized cell line, C-28/I2, used in this study exhibited a pattern of IGFBP expression similar to that which we reported previously in rat chondrocytes (Matsumoto et al. 1996a). In a preliminary study, the 


\section{IGF-I (ng/ml)}

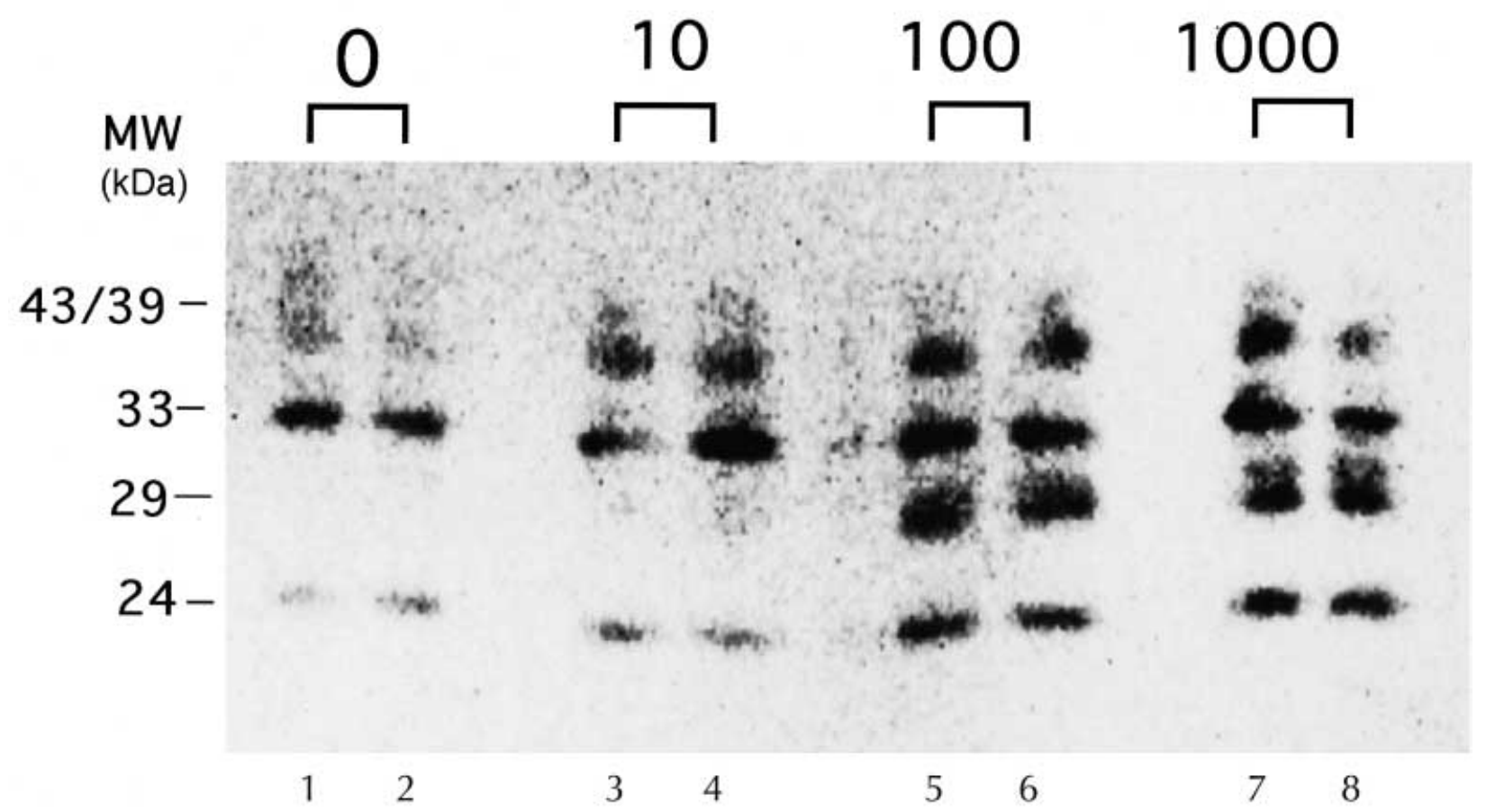

Figure 5 Western ligand blot of IGFBPs in the conditioned medium of C-28/I2 cells treated with IGF-I for $24 \mathrm{~h}$. The samples were subjected to SDS-PAGE on a 12.5\% acrylamide gel as described in Materials and Methods. Lanes 1 and 2 represent cells under basal

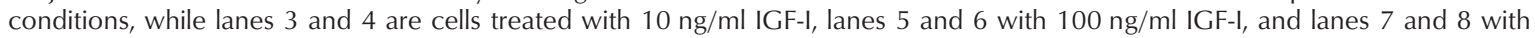
$1000 \mathrm{ng} / \mathrm{ml}$ IGF-I. The molecular mass markers of the IGFBPs are indicated on the ordinate.

$33 \mathrm{kDa}$

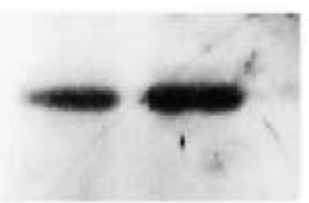

$\alpha$ IGFBP-2
$39 / 43 \mathrm{kDa}$

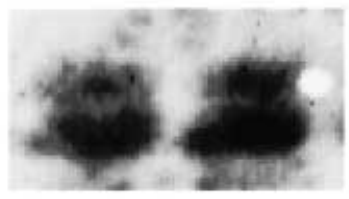

$\alpha$ IGFBP-3
$24 \mathrm{kDa}$

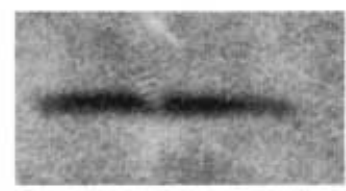

$\alpha$ IGFBP-4
29kDa

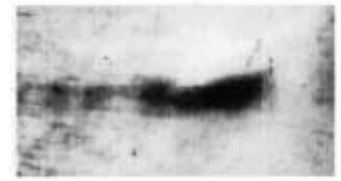

$\alpha$ IGFBP-5

\section{Immunoblotting}

Figure 6 Immunoblotting of IGFBPs. Conditioned medium of C-28/I2 cells was subjected to $12 \cdot 5 \%$ SDS-PAGE, then transferred to filters. The filters were immunoblotted with IGFBPs-2, $-3,-4$ and -5 antisera as described in Materials and Methods.

C-28/I2 cells were found to produce IGFBP-4 and IGFBP-5 at approximately five fold higher levels than IGFBP-3, and a barely detectable level of IGF-I (Goldring et al. 1996). Although our results showed direct effects of
IGFBP-3 and IGFBP-5 on IGF action, the presence of other IGFBPs, including IGFBP-4, must also be considered (Schiltz et al. 1993). The importance of IGFBP-5 in regulating IGF-I action in these cells was reflected in our 

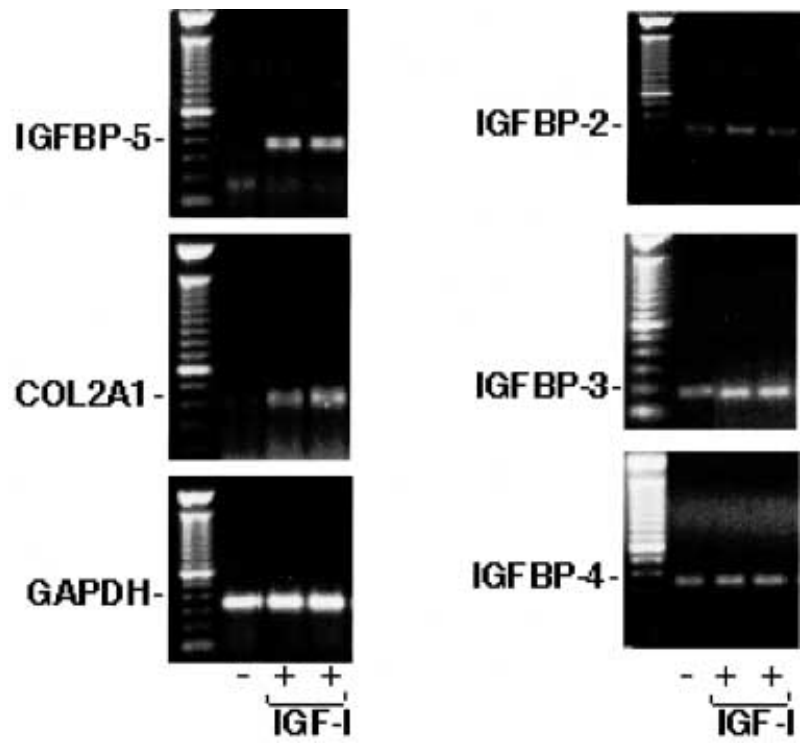

Figure 7 Comparison of IGFBP, type II collagen (COL2A1) and GAPDH mRNAs in monolayer cultures of C-28/I2 cells. The cells were passaged and cultured for 3 days in serum-containing medium. The medium was then changed to DMEM containing $0 \cdot 3 \%$ BSA, IGF-I $(100 \mathrm{ng} / \mathrm{ml})$ was added the next day, as indicated, and incubation was continued for $48 \mathrm{~h}$. The cell layers were then harvested for RNA extraction and analysis by RT-PCR, as described in the Materials and Methods. A 100 bp DNA ladder is shown in the left lane of each gel.

observation that IGF-I upregulated IGFBP-5 at both the mRNA and protein levels. While the other IGFBPs were also observed by WLB to increase dose dependently after addition of IGF-I, the small increases in expression of corresponding mRNAs suggested that the increased secretion of IGFBPs may have been due to post-translational modification.

Although the profiles of IGFBPs expressed by SV40immortalized human fibroblasts and osteoblasts were shown to be similar to those expressed by their normal counterparts (Conover et al. 1993, Durham et al. 1995), IGFBP-5 has also been shown to be downregulated in SV40-transformed human fibroblasts (Reeve et al. 1995, Schenker \& Trueb 1998). Nevertheless, our results indicate that there must be clonal variability in the responses of cells to stable expression of SV40-TAg. Since a limited number of other SV40-immortalized chondrocyte cell lines obtained by the same procedures did not express IGFBP-5 (Goldring et al. 1996), the presence of SV40 large $\mathrm{T}$ antigen did not appear to be a major consideration in our studies. Since the C-28/I2 cells do not form tumors in nude mice (Goldring et al. 1994), they are termed 'immortalized', rather than 'transformed', and thus may be expected to retain features of the chondrocyte phenotype. Although p53, which is inactivated by SV40-TAg, is known to induce IGFBP-3 with growth inhibitory properties in tumor cells carrying an inducible wild-type p53 transgene (Buckbinder et al. 1995), IGFBP-3 is present in the SV40-immortalized C-28/I2 chondrocytes at levels consistent with those reported in normal chondrocytes. Therefore, our studies indicate that the C-28/I2 cells constitute a representative model for clarifying the roles of IGFBPs in the modulation of IGF actions on chondrocytes.

In our previous studies and those of others, synovial fluid levels of IGF-I and IGFBP-3 in patients with osteoarthritis (OA) or rheumatoid arthritis (RA) were significantly increased as compared with the levels in normal subjects (Fernihough et al. 1996, Matsumoto et al. 1996c). Despite increases in IGF-I levels, destruction of cartilage tissue is found in these diseases, suggesting that OA or RA chondrocytes are hyporesponsive to IGF-I. This may be explained, in part, by the involvement of IGFBPs in the pathological process, as reported by others (Middleton \& Tyler 1992, Dore et al. 1994, Olney et al. 1996). Furthermore, increased levels of IGFBP-3 in cell lysates of osteoarthritic chondrocytes were observed while expression of the type 1 IGF receptor was normal (Tardif et al. 1996). Hyporesponsiveness to IGF-I may also explain the ineffective repair associated with the decreased capacity of arthritic chondrocytes to synthesize cartilagespecific matrix macromolecules. Since IGF-I induction of IGFBP-5 mRNA was associated with increased type II collagen mRNA in our culture model, it is tempting to speculate that changes in the balance of IGFBP-3 to IGFBP-5 may contribute to abnormal cartilage repair in arthritic joints. Further studies are needed to determine the effects of IGFBPs not only on cell proliferation but also on cartilage matrix synthesis.

In this study, we have shown the different effects of IGFBP-3 and IGFBP-5 on IGF action and binding of IGF-I to the cell membrane of chondrocytes. We conclude that interactions among IGF, IGFBPs and IGF receptor may play important roles in regulating cartilage metabolism, and that alterations of the balance among them may result in abnormal maintenance of cartilage tissue.

\section{Acknowledgements}

This work was supported in part by Grants-in-Aid for Scientific Research from the Japanese Ministry of Education, Science and Culture. This work was also supported in part by NIH grant AR45378 (M B G).

\section{References}

Andress DL \& Birnbaum RS 1992 Human osteoblast-derived insulinlike growth factor (IGF) binding protein-5 stimulates osteoblast mitogenesis and potentiates IGF action. Journal of Biological Chemistry 267 22467-22472.

Buckbinder L, Talbott R, Velasco-Miguel S, Takenaka I, Faha B, Seizinger BR \& Kley N 1995 Induction of the growth inhibitor IGF-binding protein 3 by p53. Nature 377 646-649. 
Cathala G, Savouret JF, Mendez B, West BL, Karin M, Martial JA \& Baxter JD 1983 A method for isolation of intact, translationally active ribonucleic acid. DNA 2 329-335.

Conover CA, Ronk M, Lombana F \& Powell DR 1990 Structural and biological characterization of bovine insulin-like growth factor binding protein-3. Endocrinology 127 2795-2803.

Conover CA, Kiefer MC \& Zapf J 1993 Posttranslational regulation of insulin-like growth factor binding protein-4 in normal and transformed human fibroblasts. Insulin-like growth factor dependence and biological studies. Journal of Clinical Investigation 91 1129-1137.

Cornell HJ, Enberg G \& Herington AC 1987 Preferential association of insulin-like growth factors-I and -II with metabolically inactive and active carrier-bound complexes in serum. Biochemical Journal $241745-750$.

DeMellow JS \& Baxter RC 1988 Growth hormone-dependent insulin-like growth factor binding protein both inhibits and potentiates IGF-I stimulated DNA synthesis in skin fibroblasts. Biochemical and Biophysical Research Communications 156 199-204.

Dore S, Pelletier JP, DiBattista JA, Tardif G, Brazeau P \& MartelPelletier J 1994 Human osteoarthritic chondrocytes possess an increased number of insulin-like growth factor-I binding sites but are unresponsive to its stimulation. Possible role of IGF-I-binding proteins. Arthritis and Rheumatism 37 253-263.

Durham SK, Riggs BL, Harris SA \& Conover CA 1995 Alterations in insulin-like growth factor (IGF)-dependent IGF-binding protein-4 proteolysis in transformed osteoblastic cells. Endocrinology 136 1374-1380.

Fernihough JK, Billingham ME, Cwyfan-Hughes S \& Holly JM 1996 Local disruption of the insulin-like growth factor system in the arthritic joint. Arthritis and Rheumatism 39 1556-1565.

Froger-Gaillard B, Hossenlopp P, Adolphe M \& Binoux M 1989 Production of insulin-like growth factors and their binding proteins by rabbit articular chondrocytes: relationships with cell multiplication. Endocrinology 124 2365-2372.

Goldring MB 1996 Human chondrocyte cultures as models of cartilage-specific gene regulation. In Methods in Molecular Biology: Human Cell Culture Protocols, pp 217-231. Ed. GE Jones. Totawa, New Jersey: Humana Press, Inc.

Goldring MB, Birkhead JR, Suen LF, Yamin R, Mizuno S, Glowacki J, Arbiser JL \& Apperley JF 1994 Interleukin-1 $\beta$-modulated gene expression in immortalized human chondrocytes. Journal of Clinical Investigation 94 2307-2316.

Goldring MB, Suen LF, Vereault D \& Rosen CJ 1996 Differential expression of IGF-I, IGFBPs, and cartilage matrix genes by immortalized human chondrocytes. Orthopaedic Transactions 21122 (Abstract).

Hossenlopp P, Seurin D, Segovia-Quinson B, Hardouin S \& Binoux M 1986 Analysis of serum insulin-like growth factor binding proteins using Western blotting: use of the method for titration of the binding proteins and competitive binding studies. Analytical Biochemistry 154 138-143.

Jones JI \& Clemmons DR 1995 Insulin-like growth factors and their binding proteins: biological actions. Endocrine Reviews 16 3-34.

Jones JI, Gockerman A, Busby WH Jr, Camacho-Hubner C \& Clemmons DR 1993 Extracellular matrix contains insulin-like growth factor binding protein-5: potentiation of the effects of IGF-I. Journal of Cellular Biology 121 679-687.

Kelley KM, Oh Y, Gargosky SE, Gucev Z, Matsumoto T, Hwa V, Ng L, Simpson DM \& Rosenfeld RG 1996 Insulin-like growth factor-binding proteins (IGFBPs) and their regulatory dynamics. International Journal of Biochemistry and Cell Biology 28 619-637.

Kiefer MC, Schmid C, Waldvogel M, Schlapfer I, Futo E, Masiarz FR, Green K, Barr PJ \& Zapf J 1992 Characterization of recombinant human insulin-like growth factor binding proteins-4, -5 , and -6 produced in yeast. Journal of Biological Chemistry 267 12692-12699.
Lamson G, Giudice LC \& Rosenfeld RG 1991 Insulin-like growth factor binding proteins: structural and molecular relationships. Growth Factors 5 19-28.

Lum ZP, Hakala BE, Mort S \& Recklies AD 1996 Modulation of the catabolic effects of interleukin-1 $\beta$ on human articular chondrocytes by transforming growth factor- $\beta$. Journal of Cellular Physiology 166 351-359.

McCusker RH \& Clemmons DR 1997 Use of lanthanum to accurately quantify insulin-like growth factor binding to proteins on cell surfaces. Journal of Cellular Biochemistry 66 257-267.

McCusker RH, Camacho-Hubner C, Bayne ML, Cascieri MA \& Clemmons DR 1990 Insulin-like growth factor (IGF) binding to human fibroblast and glioblastoma cells: the modulating effect of cell released IGF binding proteins (IGFBPs). Journal of Cellular Physiology 144 244-253.

McQuillan DJ, Handley CJ, Campbell MA, Bolis S, Milway VE \& Herington AC 1986 Stimulation of proteoglycan biosynthesis by serum and insulin-like growth factor-I in cultured bovine articular cartilage. Biochemical Journal 240 423-430.

Matsumoto T, Gargosky SE, Oh Y \& Rosenfeld RG 1996 a Transcriptional and post-translational regulation of insulin-like growth factor binding protein (IGFBP) -5 in rat articular chondrocytes. Journal of Endocrinology 148 355-369.

Matsumoto T, Gargosky SE, Kelley K \& Rosenfeld RG $1996 b$ Characterization of an insulin-like growth factor binding protein-5 protease produced by rat articular chondrocytes and a neuroblastoma cell line. Growth Regulation 6 185-190.

Matsumoto T, Gargosky SE, Iwasaki K \& Rosenfeld RG 1996 c Identification and characterization of insulin-like growth factors (IGFs), IGF-binding proteins (IGFBPs), and IGFBP proteases in human synovial fluid. Journal of Clinical Endocrinology and Metabolism 81 150-155.

Middleton JF \& Tyler JA 1992 Upregulation of insulin-like growth factor-I gene expression in the lesion of osteoarthritic human articular cartilage. Annals of the Rheumatic Diseases $\mathbf{5 1}$ 440-447.

Morales TI 1997 The role and content of endogenous insulin-like growth factor-binding proteins in bovine articular cartilage. Archives of Biochemistry and Biophysics 343 164-172.

Ohlsson C, Nilsson A, Isaksson OG \& Lindahl A 1992 Effect of growth hormone and insulin-like growth factor-I on DNA synthesis and matrix production in rat epiphyseal chondrocytes in monolayer culture. Journal of Endocrinology 133 291-300.

Okajima T, Iwashita M, Takeda Y, Sakamoto S, Tanabe T, Yasuda T \& Rosenfeld RG 1993 Inhibitory effects of insulin-like growth factor (IGF)-binding proteins-1 and -3 on IGF-activated glucose consumption in mouse BALB/c3T3 fibroblast. Journal of Endocrinology 136 457-470.

Olney RC, Smith RL, Kee Y \& Wilson DM 1993 Production and hormonal regulation of insulin-like growth factor binding proteins in bovine chondrocytes. Endocrinology 133 563-570.

Olney RC, Anhalt H, Neely EK \& Wilson DM 1995 A quantitative assay for IGF-I and IGF binding protein mRNAs: expression in malignant melanoma cells. Molecular and Cellular Endocrinology 110 213-223.

Olney RC, Tsuchiya K, Wilson DM, Mohtai M, Maloney WJ, Schurman DJ \& Smith RL 1996 Chondrocytes from osteoarthritic cartilage have increased expression of insulin-like growth factor I (IGF-I) and IGF-binding protein-3 (IGFBP-3) and -5, but not IGF-II or IGFBP-4. Journal of Clinical Endocrinology and Metabolism 81 1096-1103.

Reeve JG, Guadano A, Xiong J, Morgan J \& Bleehen NM 1995 Diminished expression of insulin-like growth factor (IGF) binding protein-5 and activation of IGF-I-mediated autocrine growth in simian virus 40-transformed human fibroblasts. Journal of Biological Chemistry 270 135-142. 
Schenker T \& Trueb B 1998 Down-regulated proteins of mesenchymal tumor cells. Experimental Cell Research 239 161-168.

Schiltz PM, Mohan S \& Baylink DJ 1993 Insulin-like growth factor binding protein-4 inhibits both basal and IGF-mediated chick pelvic cartilage growth in vitro. Journal of Bone and Mineral Research $\mathbf{8}$ 391-396.

Schmid C, Rutishauser J, Schlapfer I, Froesch ER \& Zapf J 1991 Intact but not truncated insulin-like growth factor binding protein-3 (IGFBP-3) blocks IGF-I-induced stimulation of osteoblasts: control of IGF signalling to bone cells by IGFBP-3specific proteolysis? Biochemical and Biophysical Research Communications 179 579-585.

Seong SC, Matsumura T, Lee FY, Whelan MC, Li XQ \& Trippel SB 1994 Insulin-like growth factor-I regulation of swarm rat chondrosarcoma chondrocytes in culture. Experimental Cell Research 211 $238-244$.
Shimasaki S \& Ling N 1991 Identification and molecular characterization of insulin-like growth factor binding proteins (IGFBP-1, -2 , $-3,-4,-5$ and -6). Progress in Growth Factor Research 3 243-266.

Sunic D, Belford DA, McNeil JD \& Weibkkin OW 1995 Insulin-like growth factor binding proteins (IGFBPs) in bovine articular and ovine growth-plate chondrocyte cultures. Biochimica et Biophysica Acta 1245 43-48.

Tardif G, Reboul P, Pelletier JP, Geng C, Cloutier JM \& MartelPelletier J 1996 Normal expression of type 1 insulin-like growth factor receptor by human osteoarthritic chondrocytes with increased expression and synthesis of insulin-like growth factor binding proteins. Arthritis and Rheumatism 39 968-978.

Received 18 November 1999

Accepted 7 March 2000 